\title{
Examination of Parental and Special Education Teachers' Attitudes towards Sports Activities of Students with Intellectual Disability
}

\author{
Sehmus Aslan \\ Faculty of Sport Sciences, Pamukkale University, Denizli, Turkey
}

Copyright $\mathrm{O} 2018$ by authors, all rights reserved. Authors agree that this article remains permanently open access under the terms of the Creative Commons Attribution License 4.0 International License

\begin{abstract}
The purpose of this study was to examine the attitudes of parents of students with intellectual disability and special education teachers working in special education schools to the sports activities of students with intellectual disability (ID). The study included 92 volunteer teachers who worked in special education schools, and 116 voluntary parents of children with ID who attended special education schools. The "Attitude Towards Sports Activities of Intellectually Disabled Individuals Scale" was used by participants to determine their attitudes towards the participation of students with intellectual disabilities. The total scale scores of the teachers and the parents were $100.39 \pm 9.41$ and $117.00 \pm 15.47$, respectively. When the scale scores of the teachers and the parents were compared, there was a statistically significant difference in favor of the parents $(p=0.000)$. The results of this study have shown that special education teachers and parents of students with intellectual disabilities have positive attitudes towards their participation in sports activities. The attitudes of the parents were found to be more positive than those of the special special education teachers.
\end{abstract}

Keywords Intellectual Disability, Sport activities, Teacher, Parents, Attitude

\section{Introduction}

Intellectual disability is defined as "limited mental functions and an inability to adapt, with marked limitations in both conceptual, social, and practical adaptive behavior, which develops before the age of 18 years" [1].

Education is an important element of life with great influence on values, beliefs and character in addition to knowledge and skills. Unfortunately, education at the level received by so-called healthy individuals has not been seen as a priority for those with special needs. Disabled individuals are excluded from society, both in terms of education and social life. Intellectually disabled children are the most common group of children with disabilities. However, these children are not well recognized by society. There are some prejudices and beliefs about these children, starting with the belief that children with intellectual disabilities cannot do anything [2].

Physical education and sports activities are known to be important for the development and adaptation of disabled individuals. Sports activities have a positive effect on the psychological and sociological aspects of an individual [3]. Through sports, the individual is motivated with the feelings of participation and sharing, and the environment and techniques applied can reduce primitive aggressive behaviour. Sports and physical activity attract mass attention and are considered to represent a healthy life [4].

Researchers have recently shown increased interest in the benefits of regular physical activity for people with intellectual disabilities. Physical exercise programs are considered to be key elements in the prevention of disease and to promote physical and emotional well-being. First, physical healing includes increased cardiovascular and respiratory muscle function, as well as the control of obesity and coronary artery disease [5]. Involvement in sports is very useful to promote the physical and mental health, social cohesion and self-confidence of children and adolescents [6,7]. Although the benefits of sports participation are well known, several previous studies have shown that children with ID have less physical activity and sports participation [8,9]. The complex and multifaceted construct of participation in physical activity involves a variety of facilitators and barriers. Factors with a positive effect on the participation of individuals with ID in physical activity are the support and opportunities provided by parents and care providers as facilitators. Negative factors forming barriers that restrict participation in physical activity, include a lack of information about physical activity, health problems, difficulties with 
transportation and level of dependence [10]. Some researchers have identified attitude-based environmental barriers, such as sports coaches having limited information about intellectual disability, and resistance or lack of emotional support from parents and other adults [11-13].

The participation of children in physical and sports activities is largely influenced by the parental attitude, and is almost the decisive factor at the point where children do not participate in these activities. Attitude is defined as a state of mind that guides behaviors [14] and thereby influences positive or negative reactions to events, objects, situations, ideas or people [9, 15-20].

Attitudes are not inherent from birth like many other behaviors, but are acquired later through learning. Parents, friends, teachers, mass media, and personal experience are some of the important factors which help to form attitudes [21]. In particular, it is impossible to deny the existence of negative judgments, and negative and exclusionary attitudes towards disabled persons. These prejudices and negative attitudes are not only encountered in society, but may also be seen within the family of the disabled person.

The purpose of this study was to examine the attitudes towards students with intellectual disability participating in sports activities, of teachers working in special education schools and the parents of intellectual disabled students.

\section{Materials and Methods}

\subsection{Research Model}

In this descriptive study, evaluation was made of the attitudes of special education teachers and parents of students with intellectual disability towards students with intellectual disability participating in sports using the "Attitude Towards Sports Activities of Intellectually Disabled Individuals Scale". Sport was accepted as activities, games, or competitions needing physical effort and skill that are played according to rules, such as football, basketball, table-tennis etc.

\subsection{Research Groups}

The study population was selected from two special education schools in Denizli, western Turkey, (Çamlık Special Education School and Tosunoğlu Special Education School), as teachers employed there and the parents of intellectually disabled students who were attending these schools. There are 102 special education teachers in the two schools, and 92 were willing to participate in the study. A total of 280 students with intellectual disability attend these schools and the parents of 116 students volunteered to participate in the study. The 92 special education teachers comprised 50 females and 42 males, and the 116 parents of the students comprised 88 females and 28 males.

Participants were divided into young adults and adults according to their age [22, 23].

Participants aged 24-35 years were classified as young adults and those aged 36 years and above, as adult. Accordingly, $55.4 \%$ of teachers and $16.41 \%$ of the parents were classified as young adults and $44.6 \%$ of the teachers and $83.6 \%$ of the parents were classified as adult. The parent group included significantly more adults than the teacher group (Table 1).

Table 1. Distribution of age groups of the teachers and parents

\begin{tabular}{c|cc|cc|cr}
\hline $\begin{array}{c}\text { Age } \\
\text { Distribution }\end{array}$ & \multicolumn{2}{|c|}{ Teachers } & \multicolumn{2}{c|}{ Parents } & \multicolumn{2}{c}{ Total } \\
\hline $\begin{array}{c}\text { Young Adult } \\
(\mathbf{2 4 - 3 5} \text { years) }\end{array}$ & 51 & $(55.4)$ & \multicolumn{1}{|c|}{19} & $16.41)$ & 70 & $(33.7)$ \\
\hline $\begin{array}{c}\text { Adults } \\
\text { (36 years and } \\
\text { over) }\end{array}$ & 41 & $(44.6)$ & 97 & $(83.6)$ & 138 & $(66.3)$ \\
\hline Total & \multicolumn{2}{|c|}{92} & \multicolumn{2}{|c|}{116} & 208 & 100.00 \\
\hline
\end{tabular}

Table 2. Gender distribution of the teachers and parents

\begin{tabular}{c|cc|cc|cc}
\hline \multirow{2}{*}{ Gender } & \multicolumn{2}{|c|}{ Teachers } & \multicolumn{2}{c|}{ Parents } & \multicolumn{2}{c}{ Total } \\
& $\mathbf{n}$ & $\mathbf{( \% )}$ & $\mathbf{n}$ & $\mathbf{( \% )}$ & $\mathbf{n}$ & $\mathbf{( \% )}$ \\
\hline Female & 50 & $(54.3)$ & 88 & $(75.9)$ & 138 & $(66.3)$ \\
Male & 42 & $(45.7)$ & 28 & $(24.1)$ & 70 & $(33.7)$ \\
\hline Total & \multicolumn{2}{|c|}{92} & \multicolumn{2}{|c|}{116} & 208 & 100.00 \\
\hline
\end{tabular}

The teacher group comprised $54.3 \%$ females and $45.7 \%$ males. The parents group comprised $75.9 \%$ females and $24.1 \%$ males.

\subsection{Data Collection Tools}

Demographic information was collected in the study using a personal information form.

Attitude Towards Sports Activities of Intellectually Disabled Individuals Scale

This scale was developed by Ilhan, Esentürk and Yarımkaya (2016) and consists of 28 items and 2 sub-dimensions as a result of exploratory factor analysis. The subscales of the scale are "Positive Attitude towards Sports Activities" (PASA) and "Negative Attitude towards Sports Activities" (NASA). The PASA subscale consists of 21 items $(1,2,3,5,6,7,9,10,11,13,14,15,17,18$, $19,21,22,23,25,26,27)$ and the NASA subscale consists of 7 items $(4,8,12,16,20,24,28)$. Responses to each item are given on a 5-point Likert type scale as Absolutely Agree (5 points), Agree (4 points), Undecided (3 points), Disagree (2 points), Absolutely Disagree (1 point). Inverse scoring is applied to the items with a negative meaning $(4,8,12,16,20,24,28)$. The total points range from $28-140$. The reliability and validity of the scale was confirmed by Ilhan, Esentürk and Yarımkaya (2016). The test-retest correlation coefficient of the scale was 0.89 and the Cronbach's alpha value was 0.96 [24].

\subsection{Analysis of the Data}

Data obtained in the study were analysed statistically using SPSS software. The Kolmogrov Smirnov test was 
applied to assess the conformity of the data to normal distribution. As the data were determined to have normal distribution, analyses were made using the t-test. A value of $p<0.05$ was accepted as statistically significant.

\section{Findings}

The statistical analysis according to determinants in terms of groups (special education teachers and parents), gender and age are presented below.

The average age of the special education teachers $(35.03 \pm 6.59$ years) was statistically significantly lower than the average age of the parents $(41.80 \pm 5.31$ years $)(p$ $=0.000)($ Table 3$)$.

Table 3. Comparison of special education teachers and parents in terms of age

\begin{tabular}{|c|c|c|c|c|c|c|}
\hline & & $\begin{array}{l}\text { Teachers } \\
\text { mean } \pm \text { SD }\end{array}$ & $\mathbf{n}$ & $\begin{array}{l}\text { Parents } \\
\text { mean } \pm \text { SD }\end{array}$ & t & $\mathbf{p}$ \\
\hline $\begin{array}{c}\text { Age } \\
\text { (years) }\end{array}$ & 92 & $35.03 \pm 6.59$ & 116 & $41.80 \pm 5.31$ & 8.20 & 0.00 \\
\hline
\end{tabular}

Both groups were found to have a high level of positive attitudes towards the sports activities children with intellectually disabled. The average scale score of the special education teachers $(100.39 \pm 9.41)$ was found to be statistically significantly lower than that of the parents $(117.07 .00 \pm 15.47)(p=0.000)($ Table 4$)$.

Table 4. Comparison of the scale scores of special education teachers and parents

\begin{tabular}{l|cc|cc|cc}
\hline & \multicolumn{2}{|c|}{$\begin{array}{c}\text { Teachers } \\
\text { mean } \pm \text { SD }\end{array}$} & n & $\begin{array}{c}\text { Parents } \\
\text { mean } \pm \text { SD }\end{array}$ & t & p \\
\hline $\begin{array}{l}\text { Scale } \\
\text { score }\end{array}$ & 92 & $100.39 \pm 9.41$ & $1167.07 .00 \pm 15.47$ & 9.04 & 0.00 \\
\hline
\end{tabular}

No statistically significant difference was determined between males and females in respect of scale scores in both groups $(\mathrm{p}=0.767)(\mathrm{p}=0.289)($ Table 5$)$.

Table 5. Comparison of the scale scores of special education teachers and parents according to gender

\begin{tabular}{c|c|c|cc}
\hline & $\begin{array}{c}\text { Female } \\
\text { mean } \pm \text { SD }\end{array}$ & $\begin{array}{c}\text { Male } \\
\text { mean } \pm \text { SD }\end{array}$ & $\mathbf{t}$ & $\mathbf{p}$ \\
\hline $\begin{array}{c}\text { Teachers } \\
(\mathbf{n}=\mathbf{9 2})\end{array}$ & $100.66 \pm 8.65$ & $100.07 \pm 10.33$ & 0.29 & 0.767 \\
\hline $\begin{array}{c}\text { Parents } \\
(\mathbf{n}=116)\end{array}$ & $116.13 \pm 16.01$ & $119.71 \pm 13.53$ & -1.06 & 0.289 \\
\hline
\end{tabular}

In the special education teacher group, the average scale score was $100.74 \pm 10.90$ for the young adults and $99.95 \pm 1.52$ for the adults. In the parent group, the average scale score was $118.78 \pm 14.82$ for the young adults and $116.64 \pm 15.65$ for the adults. No statistically significant difference was determined between the young adult and adult age groups in respect of the scale scores in the both teacher and parent groups $(\mathrm{p}=0.690)(\mathrm{p}=0.584)$ (Table 6).

Table 6. Comparison of the scale scores of special education teachers and parents according to the age groups

\begin{tabular}{c|c|c|cc}
\hline & $\begin{array}{c}\text { Young Adult } \\
\text { mean } \pm \text { SD }\end{array}$ & $\begin{array}{c}\text { Adult } \\
\text { mean } \pm \text { SD }\end{array}$ & $\mathbf{t}$ & $\mathbf{p}$ \\
\hline $\begin{array}{c}\text { Teachers } \\
(\mathbf{n}=92)\end{array}$ & $100.74 \pm 10.90$ & $99.95 \pm 1.52$ & 0.40 & 0.690 \\
\hline $\begin{array}{c}\text { Parents } \\
(\mathbf{n}=\mathbf{1 1 6})\end{array}$ & $118.78 \pm 14.82$ & $116.64 \pm 15.65$ & 0.54 & 0.584 \\
\hline
\end{tabular}

\section{Discussion and Conclusions}

From a scanning of the relevant literature, there can be seen to be a limited number of studies on the subject of sports participation of intellectually disabled children. Therefore, the findings obtained in this study will be discussed in comparison with the results of studies of special needs individuals, sports activities and general attitude studies made in the field of exercise, studies describing the current situation and research on different sample groups.

It is important to note that families with children with intellectual disability face emotional difficulties, lack of information about their children's situation, difficulties in explaining the situation of their children to other people, behavioral and health problems seen in disabled children, a lack of interviews with specialists in treatment and education, economic problems, and the one of the greatest sources of stress is anxiety about the future of the disabled child [25].

Researchers have recently shown increased interest in the benefits of regular physical activity in people with mental disabilities. Programs based on ordinary physical exercises are considered to be key elements in the prevention of disease and promotion of physical and emotional well-being $[5,10]$. However, negative attitudes of physical education teachers towards such programs and sporting events have been reported in several previous studies [26-30].

In this study, the attitudes were examined of parents of intellectually disabled students and of special education teachers and it was found that both groups have positive attitudes towards intellectually disabled students participating in sports activities. Nevertheless, the attitudes of the parents were determined to be more positive than those of the special education teachers.

These results can be attributed to the parents of intellectually disabled children being aware that sports activities are a very important tool to overcome the problems related to the intellectual disability, and their belief in the preservation of their child's well-being and that positive behavioral changes result from exercise and sports activities. When it is considered that the most powerful dimension of attitudes is the behavioral dimension, it can be said that the attitudes towards physical education lessons and sports activities of those individuals who turn sports into a behavior will naturally be more positive. It has been reported in some research that those who watch sports related programs have more 
positive attitudes to sports and physical education lessons [31]. Following sports-related programs and regularly participating in sports can be considered a sign of a positive attitude towards one's sport. In a study by Tsai and Fung (2009), the authors examined the experiences of the parents of a child with intellectual disability as they sought sports inclusive participation for their children. It was reported that most of the 49 parents in the study wanted inclusive sports involvement for their children but they did not sustain these efforts because they were rejected by staff and other participants. The factors underlying these attitude problems are a lack of understanding of ID people and a lack of contact between people with and without ID. The lack of sense of entitlement of the parents, low value placed on sport and lack of participation information and opportunities also contributed to abandoning the efforts to have their child included in sports. Factors leading to successful inclusion included the attitudes of staff and the abilities and social skills of the individuals with ID [32].

According to the gender variable in the current study, when the attitude scores of special education teachers and parents of intellectually disabled students towards sports activities were examined, male participants were seen to have higher average scores than female participants, but the difference was not of a statistically significant level. A study by Kırımlığlu et al. (2017) reported no statistically significant difference between the attitudes of male and female trainee teachers towards sports activities of intellectually disabled individuals. Previous studies on other disability groups have shown similar results in respect to gender [33-36].

The effect of age on attitude was examined and no statistically significant difference was determined between young adults and adults in respect of scale scores in both parents and teacher groups. This suggests that age does not have an effect on attitude towards exercise and sports activities of intellectually disabled children.

The results of this study have shown that special education teachers and the parents of students with intellectual disabilities have positive attitudes towards participation in sports activities by children with intellectual disabilities. Parents were observed to have more positive attitudes than the teachers. The attitude of teachers towards the classes they take during pre-service education will have an important role in all the activities they will undertake during their professional life [37]. Attitudes towards sports activities in particular are expected to significantly affect future behaviors and achievements of students [38]. Therefore, efforts should be made to improve the positive attitudes of special education teachers towards the participation of students with intellectual diasbilities in sports activities. In addition, current education and sports policies related to students with intellectual disabilities should be reviewed to ensure integration of education and sports for all.

\section{REFERENCES}

[1] R. Luckasson, S. Borthwick-Duffy, W. H. Buntinx, D. L. Coulter, E. M. Craig, A. Reeve, R. L. Schalock, M.E. Snell, D. M. Spitalnik, S. Spreat, M. J. Tasse. AAMR. Mental Retardation: Definition, Classification and Systems of Supports, 10. Edition. Washington: American Association on Mental Retardation, pp.1,8,9,42, 2002.

[2] L. İlhan. The Effect of Physical Education Upon the Socialization Levels of Mentally Handicapped Children, Kastamonu Eğitim Dergisi, Vol.16, No.1, 315-324, 2008.

[3] S. Ç. Özoğlu. Spor psikolojisi ve gelişmeler, I. International Symposium of Sports Psychology, Ankara, Bağırgan Yayınevi, 52, 1997.

[4] B. Günaydın. Evaluating the Physical Education Curriculum of the Students with Mental Disabilities According to the Opinions of the Parents and Teachers on Terms of the Content, Implementation and Problems, Master Thesis, Bolu, 2016.

[5] S. Golubovic, J. Maksimovic, B. Golubovic, N. Glumbic. Effects of exercise on physical fitness in children with intellectual disability, Research in Developmental Disabilities, Vol.33, 608-614, 2012.

[6] A. Solish, A. Perry, P. Minnes. Participation of children with and without disabilities in social, recreational and leisure activities, Journal of Applied Research in Intellectual Disabilities, Vol.23, No.3, 226-236, 2010.

[7] W. A. Marquis, B.L. Baker. Sports participation of children with or without developmental delay: Prediction from child and family factors, Research in Developmental Disabilities, Vol.37, 45-54. 2015. DOI: 10.1016/j.ridd.2014.10.028

[8] E. A. Hinckson, A. Curtis. Measuring physical activity in children and youth living with intellectual disabilities: A systematic review. Research in Developmental Disabilities, Vol.34, No.1, 72-86, 2013.

[9] N. A. Murphy, P. S. Carbone. Promoting the participation of children with disabilities in sports, recreation, and physical activities, Pediatrics, Vol.121, No.5, 1057-1061, 2008.

[10] M. Alesi, A. Pepi. Physical Activity Engagement in Young People with Down Syndrome: Investigating Parental Beliefs, Journal of Applied Research in Intellectual Disabilities, Vol.30, No.1, 71-83, 2017.

[11] M. Grandisson, S. Te' treault, A. R. Freeman. Enabling integration in sports for adolescents with intellectual disabilities, Journal of Applied Research in Intellectual Disabilities, Vol.25, No.3, 217-230, 2012.

[12] M. King, N. Shields, C. Imms, M. Black, C. Ardern. Participation of children with intellectual disability compared with typically developing children. Research in Developmental Disabilities, Vol.34, No.5, 1854-1862, 2013.

[13] R. McConkey, S. Dowling, D. Hassan, S. Menke. Promoting social inclusion through Unified Sports for youth with 
intellectual disabilities: A five-nation study, Journal of Intellectual Disability Research, Vol.57, No.10, 923-935, 2013.

[14] S. A. Arkonaç. Sosyal psikoloji, İstanbul, Alfa Yayınları, 2005.

[15] A. Tezbaşaran. Likert Tipi Ölçek Geliştirme Klavuzu, Ankara, Psikologlar Derneği Yayınları, 1996.

[16] M.F. Turgut. Eğitimde Ölçme Değerlendirme Metotları, Onuncu Baskı, Ankara, Yargıcı Matbaası, 1997.

[17] E. İ. Özgüven. Psikolojik Testler, Ankara, PDREM Yayınları, 1999.

[18] Ö. Demirel. Eğitim sözlüğü. Ankara, Pegem A Yayınları, 2001.

[19] N. Senemoğlu. Gelişim Öğrenme ve Öğretim Kuramdan Uygulamaya, Ankara, Gazi Kitapevi, (12. Bask1), 2005.

[20] M. F. Turgut, Y. Baykul. Eğitimde Ölçme ve Değerlendirme, Ankara, Pegem Akademi (5. Bask1), 2013.

[21] O. Aydın. Davranış bilimine giriş, Eskişehir: Anadolu Üniversitesi Açık Öğretim Fakültesi Yayınları, 1985.

[22] D.A. Kent, L. Quinn. Factors That Affect Quality of Life in Young Adults with Type 1 Diabetes. Diabetes Educ, 2018. doi: $10.1177 / 0145721718808733$.

[23] C. Heeyoung, K. Eunhye, K. Jihoon, K. Hyun-Joo, L. Ju-Youn, C. Jeomil, J. Ji-Young. Real-time PCR quantification of 9 periodontal pathogens in saliva samples from periodontally healthy Korean young adults, J Periodontal Implant Sci, Vol.48, No.4, 261-271, 2018.

[24] E.L. İlhan, O.K. Esentürk, E. Yarımkaya. Attitude scale of individuals having mental disabilities towards sports activities (zebseytö): Validity and reliability study, International Journal of Human Sciences, Vol.13, No.1, 1141-1160, 2016.

[25] F. Sezer. Preventive Guidance Work Towards People with Disabilities to Developing a Positive Attitude; An Experimental Application; Education Sciences, Vol.7, No.1, 16-26, 2012

[26] K. Howarth. Initial training in primary physical education no substitute for teamwork, British Journal of Physical Education, Vol.18, No.4, 152-153, 1987.

[27] N. Faucette, P. Patterson. Classroom teachers and physical education: what they are doing and how they feel about it, Education, Vol.110, No.1, $108-114,1989$.

[28] P. Xiang, S. Lowy, R. McBride. The impact of a field-based elementary physical education methods course on preservice classroom teachers' beliefs, Journal of Teaching in Physical Education, Vo.21, No.2, 145-161, 2002.

[29] Y. Arslan, F. Altay. Classroom Teachers' Views Towards Physical Education Curriculum and Implementation of Physical Education, Hacettepe J. of Sport Sciences, Vol.19, No.2, 63-79, 2008.

[30] P. Morgan, S. Bourke. Non-specialist teachers' confidence to teach PE: the nature and influence of personal school experiences in PE, Physical Education and Sport Pedagogy, Vol.13, No.1, 1-29, 2008. DOI: 10.1080/174089807013455 50

[31] E. Öncü, Ö. Güven. Attitudes of Parents Towards Participation of Their Children in Physical Education Classes, Journal of Sports and Performance Researches, Vol.2, No.2, 28-37, 2011.

[32] E.H. Tsai, L. Fung. Parents experiences and decisions on inclusive sport participation of their children with intellectual disabilities, Adapt Phys Activ Q. Vol.26, No.2, 151-71, 2009.

[33] H. Kırımoğlu, M. Dallı, A. Yılmaz, M. Say. Examination of teacher candidates' attitudes towards sportive activities of mentally disabled individuals (Muğla Sitkı Koçman Üniversity example), Journal of Human Sciences, Vol.14, No.4, 3116-3125, 2017. doi:10.14687/jhs.v14i4.4670

[34] H. Özturk, U. Abakay. Research of attitudes of the students studying in schools of physical education and sport toward disabled kids. Turkish Journal of Sport and Exercise, Vol.16, No.3, 66-68, 2014.

[35] H. Şahin, H. Bekir. Determination of University Student Attitudes Toward Disabled People, Turkish Journal of Social Work Research, Vol.3, 767-779. 2016.

[36] M. Açak, Y.E. Karakaya, Ç. Tan, Z. Coşkuner. Investigation of the Attitudes of Students from Exercise and Sports Education for Individuals with Disabilities Department Toward Individuals with Disabilities, International Periodical for the Languages, Literature and History of Turkish or Turkic, Vol.11, No.19, 1-8, 2016.

[37] H. Bağc1. An Evaluation of the Attitudes of the Candidates of Teacher of Turkish Towards Written Expression and the Courses of Written Expression, Journal of Turkology Research, Vol.21, 29-61, 2007.

[38] E. Ağgön, M. Yazıcı. Sınıf öğretmenliği programı öğrencilerinin beden eğitimi dersine yönelik tutumları (Erzincan Üniversitesi örneği), 9. Ulusal Sınıf Öğretmenliği Eğitimi Sempozyumu, Elazığg, 1072-1074, 2010. 